\title{
Educational Technological Competencies and the extent of its practice for those responsible of teaching dance *Dr/ Wessam Adel Alsayed Ameen
} Introduction:

The educational system has been considered among many systems that are affected largely by this technology in the current age, as it passes with various multiple changes and challenges . As, technology has assisted in all elements and the components of educational system where it is a teacher and a learner, an educational material, teaching and learning methods and the evaluation means, which is a matter that has imposed on it, the necessity of coping with this technology , and perception of its positive and negative sides In addition to the preparation of plans and programs aimed at developing the awarness of those working in it . Besides, what is being presented by this technology from the new things so as to push the efforts of the research and the development. Also, the reformation of the educational systems in accordance with the requirements of the technological functioning :19)

The preparation of the university graduate teacher has been considered among the most important elements that help in achieving the desired educational Renaissance that leads to a renaissance of community in all sides, and the competent teacher is the teacher who is able to achieve the goals of his educational community effectively and skillfully .Therefore, the countries that have tried to achieve a comprehensive renaissance in all sides of life will be in need for teachers who possess several competencies, and among them : Well-controlled

Lecturer at exercises, gymnastics department - Faculty of physical education, Menofia university. 
planning ,evaluation, the modern effective teaching methodology , the successful administration, the use of the means of educational technology in the teaching process. Based on this, the educational competencies have been defined as a group of capacities and needed skills for the teacher so as to succeed in performing his task, like the personal competencies, the educational, the technological and the social competencies. (28:163)

\section{Educational}

competencies have contributed in the process of preparing the physical education teacher and training him on skills and capacities he needs during educational situations. So, the preparation based on competencies has got an effective power in pushing the educational process, and preparing it fully. Also, the attitude of competencies has received a great care from educational institutions worldwide, this has indicated that it is on of the best contributions in preparing the
Physical education teacher .(15:53)

Due to the importance of the educational technological competencies for the teachers, it has been dealt with by many researchers in their studies like : Hassan Alnajar, 1997: Tsao, 2000: Saeed Ben Rashid,2000 :Ali Mohamed, 2002, :Holt, 2002: Ehsan Ben Mohamed, 2007: Hassa Ali2010: Wilson, 2010: Amna Fadil, 2011. Through this Referential survey, for the studies related to the subject of research, the researcher has reached to the following : There is no one single practical scientific study -in the limits of her knowledge - She has tried to put a list of educational technological competencies for those responsible for teaching in dance course in the faculties of the physical education and the extent of their possession to this and their practicing for these competencies in the educational process .

Through the work of the researcher in the department of the exercises and the Gymnastic and dance at the 
faculty of the physical education in the university of Menofia and its connection with many of the teaching board in the department of the dance at the faculties of physical education in the Egyptian Universities. The researcher has noticed that a large number of the teachers has lacked a lot of the educational technological competencies particularly the competencies of the using of the educational techniques, and the competencies of functioning the scientific machinery, operating them, and their maintenance reliance on the style of learning by via order ( Verbal explanation for performance of scientific model) In teaching dance course, and the lack of use of the educational technological devices in presenting the content of the theoretical and applied syllable like( the visual recorded the computer) Although their availability in the faculties of the education . From what have been presented and displayed, a matter that have attracted the concern of the researcher to specify the extent of the possession of the teachers who teach dance course and their practicing for it in teaching the dance course for female students of the faculties of physical education in the Arab Republic of Egypt, for the hope of recognizing the educational technological competencies of the teachers who teach dance course and extent of their practice of these competencies, so as to reach the results and the recommendations originated from the same environment، Accordingly the work has come marking supported with the strength and the objectivity in implementing through the points of power and their consolidation, in addition to specifying the points of weakness and trying to finding the suitable solutions for them .

\section{Research Aims :}

The research has aimed at recognizing the following:

1-Extent of possession of teachers that teach dance course for the technological competencies in some of the 
faculties of the physical education in the Arab Republic of Egypt.

2-Extent of the practicing of the teachers that teach dance course for the educational technological competencies in some of the faculties of the physical education in the Arab Republic of Egypt.

3-Relationship between the possession of the teachers that teach dance course of the educational technological competencies and their practicing of it in some of the faculties of physical education in the Arab Republic of Egypt.

\section{Research Questions:}

1 -What is the extent of the possession of teachers that teach dance course for educational technological competencies in some of the faculties of physical education in the Arab Republic of Egypt.?

2-What is the extent of the practicing of the teachers that teach dance course for the educational technological competencies in some of the faculties of physical education in the Arab Republic of Egypt?
3-Is there a relationship between the possession of the teachers that teach dance course for of the educational technological competencies in some of the faculties of the physical education in the Arab Republic of Egypt?

\section{Research Procedures:}

\section{Research methodology}

The researcher used the descriptive method by following the survey method for its suitability to the nature of the procedures of the current study .

\section{Research sample :}

The sample of research has been selected by using the intentional way from the teachers who teach dance course in the faculties of physical education in the Egyptian Universities ( Physical education faculty, Helwan university - Physical education faculty, Alexandria university - Physical education faculty, Zagazig university Physical education faculty, Tanta university - Physical education faculty, Menofia university - Physical education faculty, Assiut university - 
Physical education faculty, Beni Swef university Physical education faculty, Mansoura university - Physical education faculty, Menia university - Physical education faculty, Port Said university) and other physical education faculties have been excluded due to the absence of members of teaching board for Dance subject ) in the study year $2012 / 2013$, the total of the basic sample of research is (45) members of the teaching board , in addition to a number of (10) members of the teaching board as an exploratory Sample for rationing the main research tool (questionnaire), the percentage of the number of the teaching board has been $90 \%$ from the population of the whole research, also the percentage of the number of faculties has been $80 \%$ from the total of the number of the faculties of physical education in the Egyptian Universities , in which the dance course is taught .

Research tools:
Questionnaire For the list of educational technological competencies

The researcher has designed a list of educational technological competencies through the following steps:

1 -specifying the main domains and the special competencies in each domains according to what has been concluded from the following resources :

-The relevant studies that have dealt with the educational technological competencies for the teachers of the different subjects.

-The personal interview with several professors of the dance and the methodology of teaching the Physical education in the faculties of the physical education in the Egyptian Universities, in order to recognize the most important educational technological competencies in teaching dance course .

Based Upon what have been mentioned, the researcher has been able to design a list of the educational technological competencies in its initial picture, attachment 
(2) in accordance with the following stages :

1- The domains of the educational technological competencies are presented and distributed as seven domains :

(competencies of teaching preparing design competencies of the services of the center of the education technology means competencies of the selection of the educational devices and means-competencies of the operating of the scientific machinery and their maintenance -competencies of the used teaching strategiescompetencies of effective usage of the educational techniques-competencies in the field of evaluation) on a number of (10) professors of dance and the methodology of teaching in some of physical educational faculties (attachment 1) so as to judge the extent of the validity of the current domains, the percentages of concordance of the experts between $(80 \%$ $100 \%$ for the domains of the list of the educational technological competencies, the table (1) clarifies this.

\section{Table (1)}

The percentages of the experts' opinions in the list of the educational technological competencies $(N=10)$

\begin{tabular}{c|c|c|c|c|c}
\hline \hline \multirow{2}{*}{ Serial } & \multirow{2}{*}{$\begin{array}{c}\text { Technological } \\
\text { competencies }\end{array}$} & \multicolumn{2}{|c|}{$\begin{array}{c}\text { Opinion of the } \\
\text { expert }\end{array}$} & \multirow{2}{*}{$\begin{array}{c}\text { The } \\
\text { percentage }\end{array}$} & \multirow{2}{*}{ Ranking } \\
\cline { 3 - 5 } 1 & $\begin{array}{c}\text { Competencies of } \\
\text { teaching preparing } \\
\text { and design }\end{array}$ & 10 & -- & $100 \%$ & First \\
\hline \hline 2 & $\begin{array}{c}\text { Competencies of } \\
\text { services of the center } \\
\text { of the of educational } \\
\text { technology means }\end{array}$ & 6 & 4 & $60 \%$ & Seventh \\
\hline \hline
\end{tabular}


Follow Table (1)

The percentages of the experts' opinions in the list of the educational technological competencies $(\mathbf{N}=10)$

\begin{tabular}{|c|c|c|c|c|c|}
\hline \multirow[t]{2}{*}{ Serial } & \multirow{2}{*}{$\begin{array}{l}\text { Technological } \\
\text { competencies }\end{array}$} & \multicolumn{2}{|c|}{$\begin{array}{c}\text { Opinion of the } \\
\text { expert }\end{array}$} & \multirow{2}{*}{$\begin{array}{c}\text { The } \\
\text { percentage }\end{array}$} & \multirow[t]{2}{*}{ Ranking } \\
\hline & & Agree & disagree & & \\
\hline 3 & $\begin{array}{l}\text { Competencies of the } \\
\text { selection of the } \\
\text { educational devices } \\
\text { and means }\end{array}$ & 9 & 1 & $90 \%$ & Fifth \\
\hline 4 & $\begin{array}{l}\text { Competencies of the } \\
\text { functioning of the } \\
\text { scientific devices and } \\
\text { their maintenance }\end{array}$ & 9 & 1 & $90 \%$ & Fifth-repeated \\
\hline 5 & $\begin{array}{c}\text { Competencies of the } \\
\text { used teaching } \\
\text { strategies } \\
\end{array}$ & 10 & - & $100 \%$ & First-repeated \\
\hline 6 & $\begin{array}{l}\text { Competencies of the } \\
\text { effective usage of the } \\
\text { educational } \\
\text { techniques }\end{array}$ & 10 & - & $100 \%$ & First-repeated \\
\hline 7 & $\begin{array}{l}\text { Competencies in the } \\
\text { field of evaluation }\end{array}$ & 10 & - & $100 \%$ & repeated-First \\
\hline \multicolumn{3}{|c|}{$\begin{array}{l}\text { 2- (6) domains have been } \\
\text { specified including (59) } \\
\text { educational competencies in } \\
\text { accordance with the } \\
\text { exploratory survey of the } \\
\text { experts in the dance and } \\
\text { teaching methodology, one } \\
\text { domain has been deleted, it is: } \\
\text { ( competencies of the services } \\
\text { of the center of the educational }\end{array}$} & \multicolumn{3}{|c|}{$\begin{array}{l}\text { hasn't achieved the specified } \\
\text { percentage by the researcher in } \\
\text { accepting the domains in which } \\
\text { their percentage exceeds } 80 \% \\
\text { of the specialized concordance } \\
\text { the table (2) clarifies the } \\
\text { distribution of the list domains } \\
\text { and the number of the } \\
\text { competencies special in each } \\
\text { domains. }\end{array}$} \\
\hline
\end{tabular}
technique means) since it 
Table ( 2

Domains of the list of the educational technological competences in its initial picture.

\begin{tabular}{|c|c|c|}
\hline Domain & Technological competencies & $\begin{array}{l}\text { Number of special } \\
\text { competencies }\end{array}$ \\
\hline First & $\begin{array}{c}\text { Competencies of teaching preparation } \\
\text { and design }\end{array}$ & 11 \\
\hline Second & $\begin{array}{l}\text { Competencies of selection of the } \\
\text { education al devices and techniques }\end{array}$ & 9 \\
\hline Third & $\begin{array}{c}\text { Competencies of the used teaching } \\
\text { strategies }\end{array}$ & 10 \\
\hline Fourth & $\begin{array}{c}\text { Competencies of the effective usage of } \\
\text { the educational techniques }\end{array}$ & 10 \\
\hline Fifth & $\begin{array}{c}\text { Competencies of operating the scientific } \\
\text { devices and their maintenance }\end{array}$ & 10 \\
\hline Sixth & $\begin{array}{c}\text { Competencies of the domain of } \\
\text { evaluation }\end{array}$ & 9 \\
\hline \multicolumn{2}{|r|}{ Total } & 59 \\
\hline
\end{tabular}

3-The content of the list of the educational technological competencies has been displayed in its final form on a number of $(10)$ of the professors of the dance and the methods of teaching in the faculties of physical education (attachment 2) for the purpose of specifying the extent of the suitability of the competencies for each domain and the suitable estimation scale for the list of the education technology
This presentation has resulted in some of the suggested amendments by the experts as follows:

-Deleting some of the competencies due to repetition and similarity of meaning. -Following the scale of (yesalmost-no) by estimation degrees $(3-2-1)$

Consequently, the list of the educational technological competencies has become in its final form (attachment3) composed of six 
domains including a number of (47) competencies distributed on the different domains, under consideration, and the table number (3) clarify these domains of the list and the number of the special competencies in each domain

(Table 3)

list of the educational technological competences in its final picture.

\begin{tabular}{|c|c|c|}
\hline Domain & The name of the domain & $\begin{array}{c}\text { Number of the special } \\
\text { competencies }\end{array}$ \\
\hline$\overline{\text { First }}$ & $\begin{array}{c}\text { Competencies of teaching preparation and } \\
\text { design }\end{array}$ & 9 \\
\hline Second & $\begin{array}{c}\text { Competencies of selecting and the education } \\
\text { al devices means }\end{array}$ & 9 \\
\hline Third & Competencies of the used teaching strategies & 7 \\
\hline Fourth & $\begin{array}{c}\text { Competencies of the effective usage of the } \\
\text { educational techniques }\end{array}$ & 7 \\
\hline Fifth & $\begin{array}{l}\text { Competencies of operating the scientific } \\
\text { devices and their maintenance }\end{array}$ & 8 \\
\hline Sixth & Competencies of the domain of evaluation & 7 \\
\hline \multicolumn{2}{|r|}{$\mathrm{T}_{\mathrm{T}} \mathrm{c}$} & 47 \\
\hline $\begin{array}{l}\text { validity } \\
\text { educati } \\
\text { compet } \\
\text { has } \\
\text { consiste } \\
\text { list has } \\
\text { explora } \\
\text { of (10 }\end{array}$ & $\begin{array}{l}\text { cientific coefficients } \\
\text {-reliability) of the list } \\
\text { the educational } \\
\text { gical competencies : } \\
\text { Validity: } \\
\text { as to calculate } \\
\text { of the list of } \\
\text { nal technological } \\
\text { ncies, the researcher } \\
\text { sed the internal } \\
\text { acy validity, where the } \\
\text { been applied on an } \\
\text { ory sample consisted } \\
\text { members of the }\end{array}$ & $\begin{array}{l}\text { teaching board from the } \\
\text { population of the research and } \\
\text { outside the primary sample, } \\
\text { The correlation coefficient has } \\
\text { been calculated between the } \\
\text { degree of each competency and } \\
\text { the total degree of the domain } \\
\text { they represent . in addition to } \\
\text { the calculation of the } \\
\text { correlation coefficient between } \\
\text { the total result for each domain } \\
\text { and the current total degree, } \\
\text { both tables (4), (5) have } \\
\text { clarified that. }\end{array}$ \\
\hline
\end{tabular}


Table (4)

The correlation coefficient between the degrees of each competency and between the domain they represent in the list of the educational technological competencies $(N=10)$

\begin{tabular}{|c|c|c|c|c|c|c|c|c|c|c|c|}
\hline \multicolumn{2}{|c|}{ The first domain } & \multicolumn{2}{|c|}{$\begin{array}{c}\text { The second } \\
\text { domain }\end{array}$} & \multicolumn{2}{|c|}{$\begin{array}{l}\text { The third } \\
\text { domain }\end{array}$} & \multicolumn{2}{|c|}{$\begin{array}{l}\text { The fourth } \\
\text { domain }\end{array}$} & \multicolumn{2}{|c|}{ The fifth domain } & \multicolumn{2}{|c|}{$\begin{array}{l}\text { The sixth } \\
\text { domain }\end{array}$} \\
\hline $\begin{array}{l}\text { Comp. } \\
\text { number }\end{array}$ & $\begin{array}{l}\text { Value } \\
\text { of R. }\end{array}$ & $\begin{array}{l}\text { Comp. } \\
\text { number }\end{array}$ & $\begin{array}{l}\text { Value } \\
\text { of } R .\end{array}$ & $\begin{array}{l}\text { Comp. } \\
\text { number }\end{array}$ & $\begin{array}{l}\text { Value } \\
\text { of R. }\end{array}$ & $\begin{array}{l}\text { Comp. } \\
\text { number }\end{array}$ & $\begin{array}{l}\text { Value } \\
\text { of } R \text {. }\end{array}$ & $\begin{array}{l}\text { Comp. } \\
\text { number }\end{array}$ & $\begin{array}{l}\text { Value } \\
\text { of R. }\end{array}$ & $\begin{array}{l}\text { Comp. } \\
\text { number }\end{array}$ & $\begin{array}{l}\text { Value } \\
\text { of R. }\end{array}$ \\
\hline 1 & 0.715 & 1 & 0.770 & 1 & 0.699 & 1 & 0.759 & 1 & 0.700 & 1 & 0.796 \\
\hline 2 & 0.733 & 2 & 0.749 & 2 & 0.711 & 2 & 0.791 & 2 & 0.719 & 2 & 0.785 \\
\hline 3 & 0.760 & 3 & 0.782 & 3 & 0.730 & 3 & 0.725 & 3 & 0.780 & 3 & 0.777 \\
\hline 4 & 0.749 & 4 & 0.799 & 4 & 0.762 & 4 & 0.799 & 4 & 0.748 & 4 & 0.741 \\
\hline 5 & 0.771 & 5 & 0.700 & 5 & 0.795 & 5 & 0.762 & 5 & 0.796 & 5 & 0.760 \\
\hline 6 & 0.799 & 6 & 0.725 & 6 & 0.782 & 6 & 0.780 & 6 & 0.777 & 6 & 0.792 \\
\hline 7 & 0.774 & 7 & 0.791 & 7 & 0.733 & 7 & 0.796 & 7 & 0.791 & 7 & 0.755 \\
\hline 8 & 0.795 & 8 & 0.777 & - & - & - & - & $\Lambda$ & 0.751 & - & - \\
\hline
\end{tabular}

D.F $=8 \quad$ Significant at the level 0,05

- value of the tabulated " $r$ " at the level of $0,05=0,632$

It has been clarified by the table (4) that there is a correlation coefficient with statistically significance at the level of $(0,05)$ between the

Table (5)

degrees of each competency and the domain they belong to , a matter that indicates the credibility of the list for the

purpose it has been put for

The correlation coefficient between the grades of each domain and the total grade of the list of the educational technological competency $\mathbf{N}(10)$

\begin{tabular}{c|l|c|c}
\hline \hline Domain & \multicolumn{1}{|c|}{ Name of domain } & $\begin{array}{c}\text { Number of } \\
\text { competencies }\end{array}$ & $\begin{array}{c}\text { Correlation } \\
\text { coefficient }\end{array}$ \\
\hline \hline 1 & Competencies of teaching preparation and design & 9 & 0.749 \\
\hline 2 & $\begin{array}{l}\text { Competencies of selecting the means } \\
\text { and the educational means and devices }\end{array}$ & 9 & 0.715 \\
\hline 3 & $\begin{array}{l}\text { Competencies of the used of the } \\
\text { teaching strategies }\end{array}$ & 7 & 0.762 \\
\hline 4 & $\begin{array}{l}\text { Competencies of the effective usage of } \\
\text { the educational techniques }\end{array}$ & 7 & 0.799 \\
\hline 5 & $\begin{array}{l}\text { Competencies of operating the } \\
\text { scientific devices and their maintenance }\end{array}$ & 8 & 0.728 \\
\hline 6 & Competencies of the evaluation domain & 7 & 0.801 \\
\hline \hline
\end{tabular}

Significant at the level 0.05 
- value of the tabulated " $\mathrm{r}$ " at the level of $0.05=0.632$.

It's clear from the table (5) that the availability of the correlation coefficient with statistically significance at the level of 0.05 between the degrees of each domain and the total degree of the list of the educational technological competencies.

Second: Reliability

\section{coefficient:}

The researcher has used the method of applying the test, then reapplying, this is for the purpose of calculating the reliability coefficient o the list of educational technological competencies on the exploratory sample individuals which is composed of (10) members of the teaching board from the population of the research and outside the primary sample. The simple correlation coefficient has been calculated between the results of the two applications, the first and the second, of the complete tools. The first has been applied on 08/10/2012, and the reapplying on 23/10/2012 with a time difference estimated as (15) days, and the table (6) clarifies this .

\section{Table (6)}

\section{The coefficient of reliability of the list of educational competencies} coefficient $\quad(\mathrm{N}=10)$

\begin{tabular}{l}
\hline \hline Competencies list \\
\cline { 3 - 6 }
\end{tabular}


first and second for the list of the educational competencies which indicates that the list enjoys the reliability at a high level when being applied.

The basic study:

After specifying the members of basic research sample and reaching the educational technological competencies in its final form and confirming their credibility reliability, the researcher has applied the list of the educational technology competencies on all the members of the basic sample , which is (45) of the teachers who teach dance course, the application has been implemented on a total sample of each faculty separately, the period of application on the members of the basic research sample from 31/10/201210/01/2013.

Presentation and discussing the results

A-discussing the results related to the first question:

What is the extent of the possession of the teachers that teach dance course of for the educational technological competencies in some of the physical education faculties in the Arab Republic of Egypt ?

1-The domain of the competencies of teaching preparation and design :

The results of the table (7) have indicated that the degree of the possession of the performers of teaching dance for the educational technological competencies of teaching preparing and design in some of the physical education faculties in the Arab Republic of Egypt, has been at high degree.

The researcher has referred this result to the nature of work of the teachers that teach dance course and their possession of the teaching skills and the professional competency in addition to the needed steps to design teaching in the part of preparing the plans and specifying the goals an linking them with the activities and the evaluation with consideration to the features of the learners when forming these goals, in addition to putting the strategies in accordance with 
specified standards. As for a teacher to succeed in her job, she has to know these competencies so as to be able to achieve an effective teaching.

2- Domain of competencies of selection of the educational devices and means :

The results of the table (8) have shown that the degree of the possession of the teachers who teach the dance in some of the faculties of physical education for the competencies of selecting the educational devices and means have been at a high degree to an extent .

The researcher has referred this result that the conditions of selecting the educational devices and means might be possessed easily since they are going round the public perception of the process of selection for any educational mean, and the members of the teaching board have the ability to specify the mean and the suitable device for the practical side and the theoretical one in the syllable of the dance.
3-The domain of the competencies of the used teaching strategies :

By observing the results of the Table ( 9) it has been clear that the possession of the teachers who teach dance in some of the physical education faculties for the competencies of the used teaching strategies have been at a high degree .

The researcher has seen that the result has been due to : most of the teachers who are responsible for teaching the syllable of dance have a complete knowledge in the modern strategies and the teaching means so as to deliver the information either in the applied or theoretical dance course, they have possessed this while they have been in their academic preparation in the bachelor degree studies or the higher education studies in the faculties.

The result agrees with the results of the study of each of : Holt (2002) (12) Ehsan Kensara (2007) (9) Hassan Ali Mohamed (2010) (10) for the possession of the teachers for 
the strategies and the modern teaching methods at a high degree .

4-The domain of the competencies of the effective usage of the educational techniques .

The results of table (10) have indicated that the degree of the possession of the teachers of the dance course in some of the faculties of physical education for the competencies of the effective usage of the educational techniques, have been at a medium degree.

The researcher has refereed this result that the teachers who teach course dance in some of the faculties of physical education have relied in teaching on the method of learning via (the verbal explanation -the practical model) and that's due to the numerical increase in the number of students, also this style is the prevailing and controlling on the educational process in schools and universities, in addition to the reluctance of some of the members of teaching board to engage in the training courses for using the educational techniques in universities .

This results agree with the results of the study of each of : Tsao (2000) (30) Amna Fadil Mahmoud (2011) (5) of the lack in the number of teachers that are prepared for the effective usage of the educational techniques during the presentation of the lesson .

5-The domain of the competencies of operating the scientific devices and their maintenance:

It has become clear from the results of the table (11) that the degree of the possession of the teachers who teach the syllable of dance in some of the physical education faculties for the competencies of operating and functioning the scientific devices and their maintenance have been at a high degree.

The researcher has referred that the process of preparing the members of teaching board in the physical education faculties as a complicated process as they are prepared through a lot of training courses and 
workshops special for the means of the education technology like the computer, video, data show, serial clarifying pictures, and conducting some scientific studies based on the use of the multiple multimedia and Hypermedia , all this has contributed in increasing their scientific and practical competency .

6-The domain of the competencies of evaluation:

(12) showed that the possession of those teachers in charge of teaching the syllable of dance in some of the physical education faculties for the competencies of evaluation have been at high degree.

The researcher has referred this result to : most of those teachers in charge of teaching dance course in some of the physical education faculties are convinced with the effectively and the importance of the process of evaluation before and during teaching and after, and their concern to make the students to reach the highest level in both sides, the practical and the theoretical, In dance course. This will not be achieved without the concern of the members of the teaching board with the process of evaluation so as to recognize the extent of the cognitive and kinetic attainment for the students. This result agrees with the results of the study of each of : Hassan Alnajah Alnajar (1997) (11), Saeed ben Rashid Alsneidy (2000) (25) , Holt (2002)(12) ,Ehsan Ben Mohamed Kensara (2007) (9) Hassan Ali Ahmed (2010) (12) , Amna Fadel Mahmoud 2011) (5) on the big concern of the teachers with the competencies of evaluation during the process of learning .

B-Discussing the results related to the second question

What is the extent of the practice of teachers that teach dance course for the educational technological competencies in some of the physical education faculties in the Arab Republic of Egypt .?

1-The domain of the competencies of teaching preparation and design: 
The results of the table (13) have indicated that the degree of the practicing of the teachers that teach dance course for the competencies of teaching preparing and design of the teaching have been at high degree , from the researcher's point of view, this is due to the fact that thecourse has to be implemented at a specific time in accordance with the arranged teaching plan and this will not be achieved without the preparation of the educational lessons and their contents in addition to the used methods in the lesson and the selection of the achievement exams in which the level of the learners will be known.

2-The domain of the competencies for the selection of the educational devices and means

The results in table (14)have indicated that the degree of the practicing of the teachers who teach the syllable of dance in some of the physical education faculties for the competencies of the selection of the educational devices and means have been at a weak degree .

The researcher has refereed this result to the members of teaching board are not technical supervisors to select the means and the tools, this is a matter refer to the technicians responsible for the scientific devices and their maintenances in the faculties, and not the members of teaching board in the faculties, in addition to the lack of opportunity for the members of teaching board and students to share in committees of the selection of the educational methods and means in the faculties .

\section{3-The domain of the competencies of the used teaching strategies}

The results of the table

(15) have shown that the degree of possession of the teachers that teach dance course in some physical education faculties have been at high degree. According to the researcher this is due to the feeling of the teachers that teach dance course of the great responsible that is gave to them which is to upgrade the level 
of knowledge and practice of students. this will not be achieved but through employing strategies and teaching methods and giving considerations to the individual differences among the students during the implementation of educational lessons teaching .

4-The domain of the competencies of the effective usage of the educational techniques

The results of table (16) have shown that the degree of the practicing of the teachers of dance in some of the physical education faculties have been at high degree to an extent, a matter that agrees with this result with what have been indicated by : Soured Halts (1997) (29), Mohamed Saad ZaghloulL et al (20010) (17), the most important problems in the field of the physical education have been briefed as the unavailability of the specialized hours for teaching the subject of education technology in some of the physical educational faculties, the dis knowledge of students to how to design lessons that has education technology with their means as on integrated part of it with the rest of the lesson system and that teacher of the physical education is not concerned with making the time and effort to prepare his lessons by various multiple technological means and the unavailability of the specialized persons in the field of educational technology in the faculties of the physical education.

5- The domain of the competencies of scientific devices operation and their maintenance.

The results of table (17) have indicate that the degree of practicing of the teachers that teach dance course in some of the faculties of the physical education for the competencies of operating the scientific devices and their maintenance have been at high degree to an extent .

This could be explained on the basis of refining the teachers of dance cource after graduation through courses of refining assistants and the members of teaching broad at faculties 
making them know about the new in the technology of the physsical skills.

\section{6-The domain of the competencies of evaluation}

As indicated by table (18) that the practicing of the teachers that teach $t$ dance course in some of the faculties of physical education for the competencies of the evaluation have been at high degree. According to the researcher it has been due to the evaluation process as one of the most important stages in the educational stages to measure the outcome of the educational process, and the concern of these teachers has been based on the process of evaluation since most of them have the enthusiasm in teaching the students the dance course, so as to achieve this, It is a must to know the weak and strength points in the level of the students. In addition to their abilities to build the cognitive and kinetic tests, this result agrees with the results of the study of each of : Hassan Alnajah Alnajar (1997)(11) Saead Ben Rashid Alsneidi (2000) (25) , Ali Mohamed Saleh (2002) (4) ,Ehasan Ben Mohamed Kensara (2007)(9) Hassan Ali Ahmed (2010)(10)
C-Discussion of the results related to the third question: Has there been a relationship between the possession of the teachers responsible for teaching the syllable of dance for the educational technological competencies and their practicing to it in some of the faculties of physical education in the Arab Republic of Egypt.

The results of table (19) have indicated the availability of the correlation relationship statistically significance at the level of 0,05 between the total degree of the possession of the teachers that teach the syllable of dance for the educational technological competencies and their practicing to it, in some of the faculties of the physical education .

The researcher has referred this result to: when the educational technological competencies are available for teachers responsible for teaching the syllable of dance, the degree of their practice for it increases , and when the degree of the possession goes down, the degree of practicing these competencies goes down, this results agrees with the results of the study of each of : Saed Ben Rashid Alsnaidi (2000) (25), Ali Mohamed Saleh 
(2002) (4) Ehasan Ben Mohamed Kensara (2007) (9), Wilson (2010) (31) .

Also, this result agrees with what has been indicated by : Mumbi (2000) (22) , Pamela (2000) (23) that It is a must to use the modern technology in both fields, the practical and the theoretical .

Moreover, the importance of the usage of these technologies in thephysical education, and the necessity of training and preparing the teachers in service, the students and the teachers before service on using the computer and dealing with the technology, in addition to the necessity of making the computer available for them and for their knowledge and how to use them .

\section{Conclusions:}

1-Existence of a number of (13) educational technological competencies possessed by those responsible for teaching the syllable of dance in the faculties of physical education at a high degree from the origin of (47) competencies, at a percentage of $(27,66 \%)$.

2 -A number of (10) competencies available at a medium level from the origin of (47) competencies, at percentage of $(21,28 \%)$
3-There have been a number of (24) competencies at a little degree from the origin of (47) competencies, at a percentage of $(51,06 \%)$

4-The availability of a number of (12) competencies from the origin of (47) competencies, practiced by the teachers that teach dance course in the faculties of physical education , from their point of views at a high degree and at a percentage of $(25,53 \%)$.

5-There have been a number of (7) competencies from the origin of (47)competencies , practiced by the teachers who teach dance in the faculties of the physical education, from their point of views at a medium degree with a percentage of $(14,89 \%)$.

6 -There has been a number of (28)competencies from the origin (47) competencies practiced by the teachers who teach dance in the faculties of the physical education , from their point of views at a low degree with a percentage of $(59,57 \%)$.

7-There has been a Positive directly proportional correlation statistically significance at the level of 0.05 between the possession of the 
teachers who teach dance in the faculties of the physical education and their practice to them .

\section{Recommendations :}

In light to what have been concluded of results, the researcher has recommended the following :

1-Establishing training courses to develop the educational technological competencies for teachers who teach dance course in the faculties physical education.

2-Getting use of the list of the educational technological competencies that have been prepared by the researcher during the preparation of the assistants of the teaching broad members in the department of the exercises, gymnastics, and dance in the faculties of physical education.

3-Training on the educational technological competencies as a basic requirement within the programs of the preparation and qualifying of the assistants of the teaching board members in the department of the exercises, gymnastics, and dance in the faculties of physical education.

4-Holding training courses for the members of the teaching board in the department of the exercises, gymnastics, and dance related to the operation of the tools, devices, and the use them in the research educational purposes .

5-Addition of a teaching syllable special in the educational technological competencies within the syllables of the high education

6-The necessity to establish a special department for the education technology at the faculties of physical education.

\section{References}

1. Abdul Azim Abdul Salam Ferjani (2011): Technological Education and Technology Education, 2nd Floor, strange house for printing, publishing and distribution, Cairo.

\section{Abdul Hameed Sharaf}

(2000): Education technology in physical education, book publishing center, Cairo.

3. Abul-Naga Ahmed Izz al-Din (2005): Teaching in 
Physical Education (methodtechnique- strategies), tree Durr Library, Mansoura.

\section{Ali Mohamed Saleh} (2002): "Building a list of competencies and professional performance of the kindergarten teachers linked to growth motor", Master Thesis, Faculty of Physical Education Benin, Helwan University

5. AMNA

Fadel

Mahmoud (2011): "evaluate personal and professional skills to teach track and field in the departments and faculties of Physical Education," Journal of Physical Education, Science, Vol. IV, Issue I, Faculty of Physical Education, University of Babylon, Iraq.

6. Atef al sayed (2000): education, information technology and the use of computer and video in teaching and learning, Press Ramadan, Alexandria.

7. Bonnie, M., (1999) :

Using Technology in Physical Education

for

Classroom Teachers, Human kinetics, p. 308. Fadel Mahmoud SAFE (2011): "evaluate personal and professional skills to teach track and field in the departments and faculties of Physical Education," Journal of Physical Education, Science, Vol. IV, Issue I, Faculty of Physical Education, University of Babylon, Iraq.

8. Donal, S.,(2002): Teaching by Multimedia as Systems Approach Spot Media, New YORK

\section{EHSAN}

BIN

Mohammed Kinsara (2007): "the extent to which the faculty at the University of the members of the Umm al-Qura technological competencies and the extent of exercising them and the difficulties that they face Augeunha", educational and psychological research series, educational and psychological research institute, Umm Al Qura University, Saudi Arabia

10. Hassan

ALI AHMED:(2010): "the degree of appreciation of the importance of science teachers technological competencies in teaching vocational improve their performance", Journal of the University of Damascus, Syria, Volume 26, Issue (3) 
11. Hassan alnagah alNajjar (1997): "the availability of technical skills education teachers at the basic education level in Jordan and exercising her from the face of the teachers consider themselves", Master Thesis, Faculty of Education, Yarmouk University, Irbid, Jordan

12. Holt ,J., (2002) : The determination of computer competencies needed by classroom teachers, ERic document reproduction service , No.Ed., 410955 .

13. Mahmoud

AbdelHalim Abdul Karim (2006): dynamic teaching physical education, book publishing center, Cairo

14. Mervat Khawaja, Mustafa Sayeh (2008): entrance in physical education, fulfillment house to a minimum printing and publishing, Alexandria

15. Mohamed Mahmoud al helah (2009): Educational Technology and Informatics, 2nd Floor, University Book House, Cairo

16. Mohammed Mohammed AL Hadi (2001): e-school landmarks, the eighth Annual Scientific Conference of the Egyptian Society for Technology in Education "e- school" in the period 29-31 October

17. -Mohammed Saad Zaghloul, and others (2001): Education technology and methods in physical education, book publishing center, Cairo.

18. Mohammed Saad Zaghloul, Mustafa Sayeh (2004): preparation and qualification of teachers of Physical Education technology, fulfillment house for publication, Alexandria

19. Mohamed

Zidan

HAMDAN (2007): Teaching contemporary developments and its assets and its components and methods, 2nd Floor, Modern Education House, Amman, Jordan

20. Mostafa Abdel Samie Mohammed (1999):

Education Technology - Arab studies, the book publishing center, Cairo

21. Mostafa Badran, and others (1999): Teaching aids, the Anglo-Egyptian Library, Cairo

22. Mumbi ,K.,(2000): The impact of laptop computers on pre service teacher practicum experiences , $\mathrm{PhD}$ ، college of education, Ohio university, available at (htt://www.lipumi.com/dissertation/pervewall/9980418) 
23. Pamela,L., (2000) : How pre service teacher incorporate technology into lesson during their practice teaching experience, an intrinsic case study, $\mathrm{PhD}$, the university of Nebraska Lincoln available at : http :// www.lipumi.com/disserations/prevewall/9977024 , 9-6.

24. Roushdy toeima, Mohamed Bendary (2010): university education between reality and visions of development monitoring, Dar Arab Thought, Cairo

25. Said bin Rashid Sunaidy (2000): "Technical skills education at the Faculty of Education at Sultan Qaboos University members and the extent of her exercise," Master, Yarmouk University, Irbid, Jordan.

26. Schrum, L., \& Lamb, T.,(2003): Computer Network sasinstructional and colla bortative Distance learning Environment Available at: ( http:// www. Att. Com / learning Network / virtuelacade/ Success2. HTML2003.
27- She I Badran, Kamal Najib (2006): Higher Education and the challenges of the future, fulfillment house to a minimum printing and publishing, Alexandria

28- Smith, L., (2000): Presrvice teacher competencies for secondary educatiors of students with mild and moderate disabilities, Dissertation abstracts international, 56 (1), p., 163.

29- Soured, H.,(1997): Multimedia Electronic Tools, for Education Technology.

30- Tsao (2000): Estemate the Degree of Technology Competency Teaching At Secondary School Teacher in Aliniwe, Dissertation Abstracts. International.

31- Wilson, D., (2010): An Assessment of Educational Computing and technology of teacher Education Programs at NCATE Accredited Colleges and Universities". Dissertation Abstracts International, 55 (2), 258-A. 